\title{
PENGARUH KREDIT, INOVASI, DAN MANAJEMEN USAHA TERHADAP KINERJA KEUANGAN KOPERASI SIMPAN PINJAM
}

\author{
Nuning Nurna Dewi \\ Fakultas Ekonomi Universitas Ma’arif Hasyim Latif Sidoarjo \\ Email : nurnadewis@gmail.com
}

\begin{abstract}
This study aims to examine and analyze the effect of credit, innovation, and business management on the financial performance of savings and loan cooperatives in 8 districts in East Java. Technique of data retrieval is done by interview and kuisoner. In addition to interviews, researchers also used the financial statements of savings and credit cooperatives in 2005-2008 to determine the value of ROI (Return On Investment) on each saving and loan cooperatives. Data analysis technique in this research is done by technical analysis of inferential data. The results showed that the amount of credit, cost of innovation, and business management have a significant effect on ROI.
\end{abstract}

Keywords : savings and credit cooperatives, credit, innovation, business management

\begin{abstract}
ABSTRAK
Penelitian ini bertujuan untuk menguji dan menganalisis pengaruh kredit, inovasi, dan manajemen usaha terhadap kinerja keuangan koperasi simpan pinjam di 8 Kabupaten di Jawa Timur. Teknik pengambilan data dilakukan dengan cara wawancara dan kuisoner. Disamping dilakukan wawancara, peneliti juga menggunakan laporan keuangan koperasi simpan pinjam pada tahun 2005-2008 untuk mengetahui nilai ROI (Return On Investment) pada masing-masing koperasi simpan pinjam. Teknik analisis data dalam penelitian ini dilakukan dengan teknis analisis data inferensial. Hasil penelitian menunjukkan bahwa besar kredit, biaya inovasi, dan manajemen usaha berpengaruh signifikan terhadap ROI.
\end{abstract}

Kata kunci : koperasi simpan pinjam, kredit,inovasi, manajemen usaha

Menilik dari peran koperasi yang cukup strategis pada pertumbuhan ekonomi, maka pantaslah jika pemerintah Jawa Timur memberikan perhatian lebih kepada pemberdayaan koperasi simpan pinjam sebagai basis ekonomi kerakyatan. Pemerintah Jawa Timur memberikan kredit kepada koperasi simpan pinjam sebesar 1 Miliar rupiah untuk masing-masing koperasi dalam jangka waktu 10 tahun dengan bunga $6 \%$ per tahun. Selain modal yang berupa uang, dunia usaha memerlukan inovasi dan manajemen usaha yang tepat dan sesuai dengan kondisi organisasi. Oleh 
sebab itu, koperasi simpan pinjam juga harus mampu berinovasi dan mempunyai manajemen usaha yang tepat.

Dalam kenyataannya, kredit yang diambil oleh koperasi simpan pinjam, inovasi yang telah dilakukan oleh koperasi simpan pinjam dan manajemen usaha yang sudah dijalankan oleh koperasi simpan pinjam tidak berpengaruh kepada kinerja keuangan koperasi simpan pinjam. Kinerja keuangan yang dimaksud dalam hal ini adalah Return On Investment (ROI).

\section{TELAAH PUSTAKA}

Berdasarkan Pasal 44 Undang-Undang Nomor 25 tahun 1992 tentang Perkoperasian dan penjelasannya telah diatur bahwa koperasi dapat menghimpun dana dan menyalurkannya melalui kegiatan usaha simpan pinjam. Kegiatan usaha simpan pinjam tersebut dilaksanakan dari dan untuk anggota koperasi yang bersangkutan, calon anggota yang memenuhi syarat. Ketentuan ini menjadi dasar hukum yang kuat bagi koperasi untuk melaksanakan kegiatan usaha simpan pinjam.

Kredit yang dibahas dalam penelitian ini adalah besar kredit yang diambil oleh koperasi simpan pinjam dari pemerintah Jawa Timur dan lembaga perbankan.

Inovasi yang dimaksud dalam penelitian ini adalah biaya yang dikeluarkan selama 1 tahun yang dipergunakan untuk melakukan inovasi. Biaya yang dikeluarkan untuk melakukan inovasi diukur pengaruhnya terhadap kinerja keuangan koperasi simpan pinjam.

Manajemen usaha yang dimaksud adalah manajemen usaha yang dilakukan oleh koperasi simpan pinjam. Manajemen usaha yang dilakukan oleh koperasi simpan pinjam diukur pengaruhnya terhadap kinerja keuangan koperasi simpan pinjam.

Kinerja keuangan koperasi simpan pinjam diwakili oleh rasio return on investment yang didapat dari perhitungan membagi sisa hasil usaha koperasi simpan pinjam dengan total aktiva koperasi simpan pinjam yang dapat diketahui dari laporan keuangan koperasi simpan pinjam pada tahun 2005 sampai dengan 2008. Rasio return on investment adalah salah satu bentuk dari rasio profitabilitas yang jika nilainya semakin tinggi berarti koperasi simpan pinjam tersebut semakin profit atau semakin baik karena rasio return on investment ini menunjukkan kemampuan koperasi simpan pinjam dalam memaksimalkan keuntungan dari kegiatan operasional koperasi simpan pinjam. Rasio ini menunjukkan bahwa koperasi simpan pinjam semakin pintar mengolah total aktiva.

\section{METODE PENELITIAN}

Penelitian ini merupakan penelitian survei yaitu dilakukan dengan metode mengambil sampel dan populasi dengan menggunakan kuisoner dan wawancara. Pendekatan penelitian ini adalah pendekatan kuantitatif, dimana menitikberatkan pada pengujian hipotesis dengan menggunakan data terukur sehingga diharapkan akan dapat ditarik suatu kesimpulan. Pengujian hipotesis dilakukan dengan : Pengujian Hipotesis I (Uji F), Pengujian Hipotesis II dan III (Analisis Persamaan Regresi dan Uji t), Pengujian Adjusted $\mathrm{R}^{2}$. 


\section{HASIL ANALISISDAN PEMBAHASAN}

Dari hasil wawancara diperoleh informasi sebagai berikut:

1. Biaya inovasi yang dikeluarkan oleh masing-masing koperasi berbeda. Tergantung dari keputusan dari hasil rapat anggota koperasi. Semua koperasi simpan pinjam melakukan inovasi organisasi dengan melakukan pelatihan dan pembinaan bagi anggota dan pengurus koperasi. Inovasi teknologi juga dilakukan dengan mengganti mesin ketik menjadi komputer. Menurut pengurus koperasi bahwa inovasi pemasaran tidak perlu untuk dilakukan karena masyarakat pedesaan tidak suka membaca brosur dan selebaran disamping karena beberapa diantara masyarakatnya tidak bisa membaca dan menulis. Tata cara pemasaran Mouth to Mouth lebih dipilih untuk dilakukan karena lebih mudah untuk dilakukan. Inovasi jasa hanya dilakukan oleh koperasi simpan pinjam yang ada di kabupaten Pasuruan dengan menambah jenis pinjaman berupa pinjaman untuk melakukan ibadah haji. Untuk inovasi produk tidak dilakukan oleh semua koperasi.

2. Delapan koperasi simpan pinjam mempunyai strutur organisasi yang jelas dimana dalam struktur organisasi menggambarkan secara jelas fungsi, tugas, wewenang, setiap elemen organisasi; mempunyai kantor koperasi dan jelas kedudukannya; mempunyai sistim operasional prosedur yang jelas; mempunyai rencana kerja koperasi yang jelas; dan mempunyai administrasi yang baik dengan disertai sistim komputerisasi.

\section{Tabel 1. Hasil perhitungan ROI}

\begin{tabular}{|c|c|c|c|c|c|}
\hline \multirow{2}{*}{ No } & \multirow{2}{*}{ Nama Koperasi } & \multicolumn{4}{|c|}{ ROI } \\
\cline { 3 - 5 } & & $\mathbf{2 0 0 5}$ & $\mathbf{2 0 0 6}$ & $\mathbf{2 0 0 7}$ & $\mathbf{2 0 0 8}$ \\
\hline 1 & Tunas Artha Mandiri & 0,24 & 0,20 & 0,19 & 0,13 \\
\hline 2 & Maju Bersama & 0,41 & 0,40 & 0,39 & 0,38 \\
\hline 3 & Dana Mandiri & 0,31 & 0,22 & 0,19 & 0,17 \\
\hline 4 & Rejeki Agung & 0,29 & 0,26 & 0,24 & 0,17 \\
\hline 5 & Tani Jaya & 0,43 & 0,42 & 0,39 & 0,37 \\
\hline 6 & Lestari Mandiri & 0,10 & 0,10 & 0,09 & 0,07 \\
\hline 7 & Adi Tama & 0,26 & 0,22 & 0,19 & 0,13 \\
\hline 8 & Usaha Mandiri & 0,32 & 0,30 & 0,29 & 0,23 \\
\hline
\end{tabular}

Penurunan nilai return on investment dapat disebabkan karena terdapat pinjaman yang bermasalah. Pinjaman bermasalah masuk dalam account total aktiva sebagai piutang tak tertagih. Dengan adanya pinjaman yang bermasalah yang nilainya semakin tinggi setiap tahunnya, maka nilai total aktiva semakin tinggi dan hal tersebut menyebabkan nilai total aktiva lebih besar dari sisa hasil usaha sehingga rasio return on investment pada 8 koperasi simpan pinjam menurun setiap tahunnya.

Penjelasan hubungan antara variabel-variabel melalui pengujian hipotesisadalah sebagai berikut: 


\section{Pengujian Hipotesis I (Uji F)}

\section{Tabel 2. Pengujian Hipotesis I}

\section{ANOVA $^{\text {b }}$}

\begin{tabular}{|c|c|r|r|r|r|c|}
\hline \multicolumn{2}{|c|}{ Model } & $\begin{array}{c}\text { Sum of } \\
\text { Squares }\end{array}$ & df & $\begin{array}{c}\text { Mean } \\
\text { Square }\end{array}$ & $F$ & Sig. \\
\hline \multirow{3}{*}{1} & Regression & 0.176 & 3 & 0.059 & 9.18 & $.000^{\mathrm{a}}$ \\
\cline { 2 - 7 } & Residual & 0.179 & 28 & 0.006 & & \\
\cline { 2 - 7 } & Total & 0.354 & 31 & & & \\
\hline
\end{tabular}

a. Predictors: (C onstant), X3, X1, X2

b. Dependen Variable: $Y$

$\mathrm{F}_{\text {hitung }}$ dan $\mathrm{F}_{\text {tabel }}$ digunakan untuk menguji apakah besar kredit, biaya inovasi dan manajemen usaha berpengaruh signifikan terhadap return on investment. Karena $\mathrm{F}_{\text {hitung }}>\mathrm{F}_{\text {tabel }}$, maka dapat disimpulakan besar kredit, biaya inovasi dan manajemen usaha berpengaruh signifikan terhadap return on investment. Berdasarkan Tabel dapat diketahui bahwa nilai probabilitas 0,000, maka besar probabilitas < taraf signifikansi, artinya besar kredit, biaya inovasi dan manajemen usaha berpengaruh signifikan terhadap return on investment.

1. Pengujian Hipotesis II dan III (Analisis Persamaan Regresi dan Uji t)

\section{Tabel 2. Pengujian Hipotesis II dan III}

\section{COEEFICIENTSa}

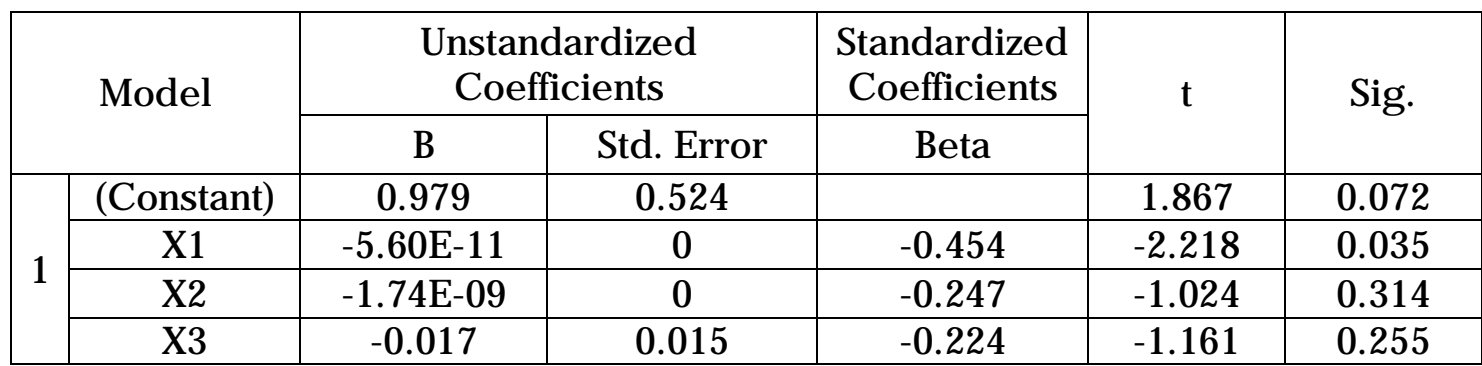

a. Dependen Variable: $Y$

Dengan melihat hasil pada tabel coefficients, maka persamaan regresi yang dapat dibuat adalah:

$$
Y=0,979-0,000000000056 X_{1}-0,0000000017 X_{2}-0,017 X_{3}
$$

Berdasarkan tabel diketahui $\mathrm{t}$ hitung $<$ - $\mathrm{t}$ tabel maka Ho ditolak, artinya kredit berpengaruh nyata terhadap kinerja keuangan koperasi simpan pinjam. Nilai $t$ pada $X_{1}$ bernilai negative, artinya besar kredit yang diambil oleh koperasi simpan pinjam berpengaruh negatif terhadap rasio return on investment. Artinya, jika besar kredit naik maka rasio return on investment turun begitu juga sebaliknya. Hal ini disebabkan jika besar kredit yang diambil oleh koperasi naik maka beban operasional yang harus ditanggung oleh koperasi juga mengalami kenaikan. Beban operasional akan mengalami kenaikan jika besar kredit mengalami kenaikan karena koperasi simpan pinjam harus membayar pokok pinjaman dan bunga pinjaman. Dengan adanya kenaikan beban operasional maka SHU koperasi akan mengalami penurunan. Jika SHU mengalami penurunan maka rasio return on investment akan mengalami penurunan. 
Berdasarkan Tabel diketahui nilai $\mathrm{t}$ hitung $>-\mathrm{t}$ tabel maka Ho diterima, artinya inovasi tidak berpengaruh nyata terhadap kinerja keuangan koperasi simpan pinjam. Karena nilai probabilitas > taraf signifikansi maka Variabel manajemen usaha tidak signifikan terhadap rasio return on investment karena manajemen usaha koperasi tidak mengalami perubahan dari tahun 2005-2008.

\section{Pengujian Adjusted $\mathbf{R}^{\mathbf{2}}$}

\section{Tabel 3. Pengujian Adjusted $\mathbf{R}^{2}$}

\section{Model Summary}

\begin{tabular}{|c|c|r|r|c|}
\hline Model & $R$ & $\begin{array}{c}R \\
\text { Square }\end{array}$ & $\begin{array}{c}\text { Adjusted } \\
\text { R Square }\end{array}$ & $\begin{array}{c}\text { Std. Error } \\
\text { of the } \\
\text { Estimate }\end{array}$ \\
\hline 1 & $.704^{\mathrm{a}}$ & 0.496 & 0.442 & 0.079869 \\
\hline
\end{tabular}

a. Predictors: (Constant), X3, X1, X2

b. Dependen Variable: $Y$

Koefisien korelasi (R) sebesar 0,704, nilai ini belum mendekati angka 1 tetapi nilai ini diatas 0,50 maka hubungan antara variabel-variabel independen $\left(X_{1}, X_{2}, X_{3}\right)$ dan dependen $(Y)$ erat. Korelasi antara variabel dependen dan inependen bersifat positif. Artinya, jika nilai $\mathrm{X}$ naik, maka akan direspon dengan kenaikan nilai $Y$. Nilai adjusted $R^{2}$ sebesar 0,442 , artinya bahwa $44,2 \%$ return on investment dipengaruhi oleh kredit, biaya inovasi, dan manajemen usaha.

\section{SIMPULAN}

1. Delapan koperasi simpan pinjam tidak hanya mengambil kredit dari Pemerintah Jawa Timur tetapi juga mengambil kredit lembaga perbankan antara lain : Bank Jatim, Bank Padi, dana kredit pupuk dan Bank Mandiri.

2. Inovasi yang dilakukan oleh 8 koperasi simpan pinjam adalah inovasi organisasi dan inovasi teknologi. Untuk inovasi pemasaran tidak dilakukan karena 8 koperasi simpan pinjam lebih memilih cara pemasaran melalui mouth to mouth. Inovasi produk dan logistik juga tidak dilakukan oleh koperasi simpan pinjam. Untuk inovasi jasa hanya dilakukan oleh koperasi simpan pinjam di kabupaten Pasuruan sedangkan 7 kabupaten yang lain tidak melakukan inovasi jasa.

3. Hasil analisis yang dilakukan menunjukkan bahwa besar kredit, biaya inovasi, dan manajemen usaha berpengaruh signifikan terhadap rasio return on investment.

4. Untuk perhitungan masing-masing variabel, besar kredit berpengaruh signifikan terhadap rasio return on investment sedangkan biaya inovasi dan manajemen usaha tidak berpengaruh signifikan terhadap return on investment karena besar biaya yang dikeluarkan untuk melakukan inovasi dan menajemen usaha yang dilakukan tidak mengalami perubahan (sama) setiap tahunnya. 
DAFTAR PUSTAKA

Arif Pratisto. Statistik Menjadi Mudah dengan SPSS 17. Elex Media Komputindo. Jakarta. 2009

Bambang Wahyuono. Best Practice Koperasi Simpan Pinjam / Usaha Simpan Pinjam. 2008

Koperasi di Jatim. 2008

Dinas Koperasi Pengusaha Kecil dan Menengah Provinsi Jawa Timur. Pedoman Standar Operasional, Manajemen Koperasi Simpan Pinjam dan Unit Simpan Pinjam Koperasi. 2007

Dinas Koperasi Pengusaha Kecil dan Menengah Provinsi Jawa Timur. Undang-Undang Republik Indonesia nomor 25 tahun 1992, 2007

Djoko Wintoro. Dampak Inovasi Pemasaran Terhadap Struktur Modal dan kinerja perusahaan. Jurnal Keuangan dan Perbankan Unmer Malang Vol 12 Januari. Malang. 2007

Ino dan Fendy S. Psikologi Industri dan Organisasi. Fakultas Psilkologi Universitas Airlangga. Surabaya. 2005

Marina Van Geenhuizen. Hubungan Anatara Akses Terhadap Informasi dan Inovasi:Studi Empiris Usaha Kecil dan Menengah di Indonesia. Jepara. 2005

Munawir. Analisa Laporan Keuangan. Liberty. Yogyakarta. 2001

Robbins dan Stephen P. Perilaku Organisasi. PT Indeks. Jakarta. 2003

Sambas Ali Muhidin dan Maman Abdurahman. Analisis korelasi, Regresi, dan Jalur Dalam Penelitian. Pustaka Setia Bandung. Bandung. 2007

Sofyan Safri Harahap. Analisis Kritis Atas Laporan Keuangan. 1999 